\title{
Multi-Log Cytotoxicity of Carbocyclic 2'-Deoxyguanosine in HSV-TK-Expressing Human Tumor Cells
}

\author{
DONNA S. SHEWACH, ${ }^{1}$ PATRICK J. MURPHY, ${ }^{1}$ BLAINE W. ROBINSON,${ }^{1}$ JENNIFER VULETICH, ${ }^{1}$ \\ PAUL D. BOUCHER, ${ }^{1}$ ANNA L. BLOBAUM,${ }^{1}$ LAURA ZERBE, ${ }^{1}$ JOHN A. SECRIST III, ${ }^{2}$ \\ and WILLIAM B. PARKER ${ }^{2}$
}

\begin{abstract}
Ganciclovir (GCV) is widely used as a prodrug for selective activation in tumor cells expressing herpes simplex virus thymidine kinase (HSV-TK) because of its ability to induce multi-log cytotoxicity to HSV-TK-expressing as well as nonexpressing bystander cells. We now report that another substrate for HSV-TK, D-carbocyclic 2'-deoxyguanosine (CdG), induces multi-log cytotoxicity in HSV-TK-expressing and bystander cells at concentrations $\leq 3 \mu M$. We have compared the cytotoxicity and cell cycle effects of $\mathrm{CdG}$ to that observed with GCV in two human tumor cell lines. The results demonstrated that cytotoxicity of CdG was similar to that of GCV in both U251 glioblastoma and SW620 colon carcinoma cells that stably expressed HSV-TK. In addition, CdG induced a potent bystander effect in both cell types in co-cultures consisting of HSV-TK-expressing and nonexpressing bystander (lacZ-expressing) cells at ratios of 50:50 or 10:90. Selectivity for HSVTK-expressing compared to lacZ-expressing cells was similar for CdG and GCV in the U251 cells, however CdG was less selective than GCV in the SW620 cell lines. Despite their ability to induce multi-log cytotoxicity at similar concentrations, CdG and GCV exhibited differential effects on cell cycle progression. Cells incubated with $1 \mu M \mathrm{CdG}$ for $24 \mathrm{hr}$ accumulated in $\mathrm{S}$-phase and $\mathrm{G}_{2} / \mathrm{M}$ after drug washout, and the majority of cells died prior to cell division. This contrasts with the delayed effects of $1 \mu M$ GCV that were not evident until after cell division when cells attempted $S$-phase for the second time. Thus, CdG is a potent cytotoxic agent that merits further investigation to determine whether it will be therapeutically effective in enzymeprodrug therapy with HSV-TK.
\end{abstract}

\section{OVERVIEW SUMMARY}

We have evaluated D-carbocyclic 2'-deoxyguanosine (CdG) as a prodrug for activation by the herpes simplex virus thymidine kinase (HSV-TK) stably expressed in human tumor cells. Similar to previous findings with ganciclovir (GCV), CdG elicited multi-log cell killing at micromolar concentrations in two different cell lines. CdG also displayed potent bystander cytotoxicity even when HSV-TK was expressed in only $10 \%$ of the cells in the culture. HSV-TK-expressing cells incubated with $C d G$ accumulated in $G_{2} / M$, in contrast to the delayed S-phase arrest observed previously with GCV. Thus, CdG is a potent cytotoxic agent for enzyme-prodrug cancer therapy with HSV-TK that merits further investigation.

\section{INTRODUCTION}

$\mathbf{T}$ RANSFER OF A FOREIGN ENZYME into tumor cells to activate a nontoxic prodrug has been proposed as a more selective approach to cancer chemotherapy (Moolten, 1994). One of the more promising of these gene therapy approaches uses transfer of the herpes simplex virus thymidine kinase (HSV-TK) cDNA followed by treatment with the antiviral nucleoside analog ganciclovir (GCV). The HSV-TK phosphorylates GCV to its monophosphate, and subsequently cellular kinases phosphorylate it further to the di- and triphosphate derivatives (Keller $e t$ al., 1981; Cheng et al., 1983; Field et al., 1983; Boehme, 1984; Biron et al., 1985). GCV triphosphate then competes with dGTP for incorporation into DNA to elicit cytotoxicity (Cheng et al., 1983; St.Clair et al., 1987; Reid et al., 1988; Reardon, 1989;

\footnotetext{
${ }^{1}$ Department of Pharmacology, University of Michigan Medical School, Ann Arbor, MI 48109.

${ }^{2}$ Southern Research Institute, Birmingham, AL 35205.
} 
Ilsley et al., 1995). Because GCV is not a good substrate for any of the endogenous mammalian kinases, this approach should be more selective than traditional nucleoside analogs which can be phosphorylated in many normal host tissues. The combination of HSV-TK/GCV has produced complete tumor regressions in animal models (Moolten, 1986; Culver et al., 1992). In addition, even when only $10 \%$ of the tumor expressed the activating HSV-TK, complete tumor regressions have been obtained (Culver et al., 1992; Ram et al., 1993; Link et al., 1997). The ability to kill neighboring non-HSV-TK-expressing cells, termed the bystander effect (Freeman et al., 1996; Pope et al., 1997), is important because current methods for gene transfer will result in transgene expression in only a small percentage of the tumor cells (Roth and Cristiano, 1997).

Despite the excellent antitumor activity of GCV in preclinical models, HSV-TK/GCV has not shown efficacy in human trials (Shand et al., 1999; Rainov, 2000; Trask et al., 2000). This has been attributed in part to the low delivery of the HSVTK cDNA to tumors using currently available methodologies. In the absence of improved delivery techniques, investigators have attempted to improve HSV-TK enzyme-prodrug therapy by enhancing the affinity of HSV-TK for GCV (Black et al., 1996; Kokoris et al., 1999; Qiao et al., 2000), improving bystander cell killing (Park et al., 1997; Touraine et al., 1998; Carystinos et al., 1999; Boucher et al., 2000; Robe et al., 2000), combining it with other modalities (Castleden et al., 1997; Aghi et al., 1998; Freytag et al., 1998; Wildner et al., 1999), or identifying better substrates for HSV-TK (Degreve et al., 1999). We and others have reported previously that GCV was significantly more cytotoxic to cells expressing HSV-TK than other substrates (Rubsam et al., 1998; Degreve et al., 1999). Our studies have demonstrated that GCV produced multi-log cell killing at submicromolar concentrations (Shewach et al., 1994; Boucher et al., 1998; Rubsam et al., 1998). GCV triphosphate was shown to be highly potent, in which an intracellular concentration of 5-10 $\mu \mathrm{M}$ was sufficient to kill $>3$ logs of cells (Rubsam et al., 1998; Boucher et al., 1998). Other substrates could achieve higher triphosphate concentrations but produced $<1.5 \log$ s of cell death. Mechanistically, GCV differed from classical nucleoside analogs in that cells divided once after incubation with GCV, then arrested permanently during the S-phase following cell division (Rubsam et al., 1998). The high potency of GCV triphosphate appears to explain the ability of GCV to kill non-HSV-TK-expressing bystander cells adjacent to HSV-TK-expressing cells. Transfer of phosphorylated GCV from HSV-TK-expressing to nonexpressing bystander cells resulted in low but highly cytotoxic levels of GCV triphosphate (Bi et al., 1993; Ishii-Morita et al., 1997; Boucher et al., 1998; Rubsam et al., 1999).

On the basis of the unique toxicity of GCV, we have searched for other similarly effective analogs. We have noted that the experimental antiviral drug D-carbocyclic 2 '-deoxyguanosine $(\mathrm{CdG})$ was also capable of inducing multi-log cell killing at low concentrations. Similar to $\mathrm{GCV}, \mathrm{CdG}$ is a guanine nucleoside analog with therapeutic activity in herpes virus infections due to its ability to be phosphorylated by the herpes-encoded thymidine kinase and subsequently become incorporated into DNA (Bennett et al., 1990, 1993; Parker et al., 1992). We hypothesized that the unique multi-log cell killing observed with these drugs may share a common pathway. Thus, we undertook an evaluation of the cytotoxicity and cell cycle effects for CdG. We also assessed the ability of CdG to induce killing of nonHSV-TK-expressing bystander cells, because this is an important requirement for drugs in a gene transfer enzyme-prodrug approach to cancer chemotherapy. A preliminary account of a portion of these results has been reported (Murphy et al., 1999).

\section{MATERIALS AND METHODS}

\section{Cell culture}

U251 human glioblastoma cells were cultured in RPMI-1640 medium supplemented with $2 \mathrm{~m} M$ L-glutamine and $10 \%$ bovine calf serum (Life Technologies Inc., Grand Island, NY). SW620 human colon carcinoma cells were cultured in McCoy's 5a medium supplemented with $2 \mathrm{~m} M$ glutamine and $10 \%$ fetal calf serum (Life Technologies Inc., Grand Island, NY). Cell cultures were maintained in exponential growth at $37^{\circ} \mathrm{C}$ in a humidified atmosphere containing $5 \% \mathrm{CO}_{2}$. Each cell line had previously been stably transduced with a retroviral vector containing the cDNA for herpes simplex virus type 1 thymidine kinase or $\beta$-galactosidase $(\beta$-Gal) and monoclonal sublines were developed for each transgene (Boucher et al., 1998; Rubsam et al., 1998).

\section{Cell survival assays}

Exponentially growing cells were incubated with drug for 4-24 $\mathrm{hr}$ and cell survival was measured by a colony formation assay as previously described (Boucher et al., 1998; Rubsam et al., 1998). Briefly, cultures of $100 \%$ HSV-TK-expressing or $100 \% \beta$ Gal-expressing cells were harvested at the conclusion of the drug incubation period and diluted to plate approximately $10-100 \mathrm{vi}-$ able cells in a 35-mm-diameter well in 6-well culture plates. Three to six wells were plated with the same number of cells to estimate viability at each drug concentration. After 10-14 days, the resulting colonies were fixed and stained with $0.4 \%$ crystal violet, and colonies of at least 50 cells each were enumerated. For coculture experiments with HSV-TK- and $\beta$-Gal-expressing cells, cells were plated as described, and $\beta$-Gal-expressing (bystander) colonies were detected by staining with $0.2 \%$ 5-bromo-4-chloro3 -indolyl- $\beta$-D-galactoside (X-Gal, Boehringer Mannheim, Indianapolis, IN). After enumeration of the $\beta$-Gal-positive colonies, the culture dish was stained with crystal violet and all colonies enumerated. The difference between the number of crystal violetstained colonies and $\beta$-Gal-expressing colonies yielded the number of HSV-TK-expressing colonies. Cell survival was expressed as a fraction of plating efficiency for control (no drug treatment) cells. All colony formation assays were performed at least twice.

\section{Cell cycle analysis}

Flow cytometric analysis was performed essentially as described (Ostruszka and Shewach, 2000). Control or drug-treated cells were incubated with bromodeoxyuridine for $15 \mathrm{~min}$, harvested, washed and fixed with $70 \%$ ethanol. Within $6 \mathrm{hr}$ prior to flow cytometric analysis, fixed cells were washed, and incubated with RNase A for $30 \mathrm{~min}$ at $37^{\circ} \mathrm{C}$. DNA was denatured by treatment with $0.1 \mathrm{~N} \mathrm{HCl}$ containing $0.7 \%$ Triton $\mathrm{X}-100$, then resuspended in $\mathrm{dH}_{2} \mathrm{O}$ and incubated at $95^{\circ} \mathrm{C}$ for $15 \mathrm{~min}$. 
Cells were washed and resuspended in phosphate-bufferedsaline (PBS) with $0.5 \%$ Tween 20 and $5 \%$ calf serum, followed by the addition of anti-bromodeoxyuridine mouse immunoglobulin $\mathrm{G}_{1}$ $\left(\mathrm{IgG}_{1}\right)$ antibody (PharMingen, San Diego, CA). After centrifugation, fluorescein isothiocyanate (FITC)-conjugated goat antimouse IgG antibody (Sigma Chemical Co., St. Louis, MO) was added for detection of the primary antibody, and propidium iodide was added to label total DNA. Trout erythrocyte nuclei(Biosure, Grass Valley, CA) were added as an internal standard. Cells were analyzed using a Coulter EPICS Elite ESP flow cytometer, and the cell cycle distribution was determined using WinMDI software provided by Joseph Trotter of The Scripps Research Institute. For measurement of apoptosis, cells were fixed and treated with propidium iodide and RNase A only, and analyzed by flow cytometry for cells with sub- $\mathrm{G}_{1}$ content.

\section{RESULTS}

\section{Cytotoxicity of CdG in HSV-TK- or LacZ-expressing U251 cells}

U251 cells were incubated with a broad range of CdG concentrations for $24 \mathrm{hr}$ and survival was determined using a colony formation assay. As illustrated in Fig. 1A, U251 cells expressing HSV-TK (U251tk) exhibited similar sensitivity to CdG and $\mathrm{GCV}$, with the $\mathrm{IC}_{50}$ value for each drug approximately 0.06 $\mu M$. In addition, $\mathrm{CdG}$ and GCV produced multi-log cell killing in the U251tk cells, with approximately $3 \log$ s of cell killing at $1 \mu M$. Less toxicity was evident in U251 cells expressing $\beta$ Gal (U251lacZ), with $\mathrm{IC}_{50}$ values of 40 and $60 \mu M$ for $\mathrm{CdG}$ and GCV, respectively, and at $1000 \mu M$ both drugs induced approximately 1-1.5 log decreases in cell survival (Fig. 1B). Shorter incubation periods with $\mathrm{CdG}$ also induced multi-log cytotoxicity with $\mathrm{U} 251$ tk cells, with $10 \mu M \mathrm{CdG}$ producing 2 to $3 \log$ s of cell death following incubation periods of 4-12 hr (Fig. 2). At a concentration of $1 \mu M$, the $4-\mathrm{hr} \mathrm{CdG}$ incubation reduced cell survival by $70 \%$, and a $24-\mathrm{hr}$ exposure decreased survival to $<0.5 \%$. The corresponding L-isomer of $\mathrm{CdG}$ did not show significant cytotoxicity in these cell lines, with $>95 \%$ cell survival following a $24 \mathrm{hr}$ incubation with $100 \mu M_{\mathrm{L}-\mathrm{CdG}}$ in U251tk cells (data not shown).

\section{Cytotoxicity of CdG in U251 Co-cultures of HSV-TK- expressing and nonexpressing bystander cells}

HSV-TK-expressing U251 cells were co-cultured with U251lacZ bystander cells to evaluate the ability of $\mathrm{CdG}$ to induce bystandercell killing. When $50 \%$ of the cells in the co-culture expressed HSV-TK, the effect of CdG in the HSV-TK-expressing cells was similar to that in the $100 \%$ HSV-TK-expressing culture (Fig. 3; $\mathrm{IC}_{50}=0.04 \mu M$ ). Although CdG was somewhat less toxic to the bystander cells, killing was still impressive with an $\mathrm{IC}_{50}$ value of $0.2 \mu M$. When only $10 \%$ of the co-culture expressed HSV-TK, the sensitivity to CdG was reduced approximately 10fold in both the HSV-TK-expressing and bystander cell populations, with $\mathrm{IC}_{50}$ values of 0.4 and $3 \mu M$, respectively. Notably, $\mathrm{CdG}$ was able to induce $\geq 1 \log$ reduction in cell survival in HSVTK-expressing and bystander cells when present in co-culture at a ratio of 50:50 $\left(\mathrm{IC}_{90}=0.25\right.$ and $1.0 \mu M$, respectively $)$ or 10:90 ( $\mathrm{IC}_{90}=5$ and $7 \mu M$, respectively).

\section{Cell cycle progression}

With the similarity in cytotoxicity for $\mathrm{CdG}$ and $\mathrm{GCV}$, we wished to determine whether CdG killed cells by the novel mechanism proposed for GCV. Previously, we observed that cells incubated with GCV were slowed in their ability to progress through the cell cycle, but they doubled following a 24-hr GCV incubation and then arrested in the subsequent S phase (Rubsam et al., 1998). We performed dual-parameter (bromodeoxyuridine incorporation and propidium iodide staining) flow cytometry on U251tk glioblastoma cells following incubation with $1 \mu M \mathrm{CdG}$ for $24 \mathrm{hr}$. As indicated in Table 1, after a 24-hr incubation with $\mathrm{CdG}$ the percentage of cells in $\mathrm{G}_{1}$ decreased by almost four-fold, with a nearly two-fold increase in the percentage of cells in $S$ and $G_{2} / M$. By $48 \mathrm{hr}$ after drug washout, the $\mathrm{S}$-phase percentage decreased with a concomitant increase in $G_{1}$, but the $G_{2} / M$ population remained high. There was a slight increase in cell number at $24 \mathrm{hr}$ after drug washout; however, the cell number decreased over the next $48 \mathrm{hr}$. These data indicate that at best only a small portion $(<27 \%)$ of the cell population divided. Some of the cells appeared to die in S-phase as evidenced by the two- to four-fold increase in the percentage of cells in S-phase that did not incorporate bromodeoxyuridine $\left(\mathrm{S}_{\mathrm{NI}}\right)$. CdG was able to induce apoptosis; however, this was a delayed effect that appeared at least $48 \mathrm{hr}$ after drug washout. Thus, most cells exposed to $\mathrm{CdG}$ died without going through cell division.

\section{Cytotoxicity in SW620 colon carcinoma cells}

We wished to determine whether effects of $\mathrm{CdG}$ in the SW620 human colon carcinoma cells were similar to those that we observed previously with GCV. SW620 cells that stably expressed either HSV-TK (SW620tk) or $\beta$-Gal (SW620lacZ) were used for these studies. As shown in Table 2, CdG was less potent than $\mathrm{GCV}$, but $\mathrm{CdG}$ was able to induce $\geq 1 \log$ cytotoxicity at micromolar concentrations. $\mathrm{CdG}$ showed similar potency to GCV in killing bystander cells co-cultured with $10 \%$ or $50 \%$ HSV-TK-expressing SW620 cells. Furthermore, the bystander killing ability of $\mathrm{CdG}$ could be augmented synergistically by the addition of hydroxyurea at concentrations ranging from 0.5 to $4 \mathrm{~m} M$ (data not shown), as we have demonstrated previously for GCV (Boucher et al., 2000).

The major distinction between $\mathrm{CdG}$ and GCV in these studies was in the cytotoxicity to $100 \%$ cultures of lacZ-expressing SW620 bystander cells. The SW620lacZ cells were approximately five-fold more sensitive to $\mathrm{CdG}$ than GCV based on relative $\mathrm{IC}_{50}$ concentrations. In addition, the relative $\mathrm{IC}_{50}$ values for $\mathrm{CdG}$ in $100 \%$ cultures of SW620lacZ and SW620tk cells differed by 100 -fold, whereas there was a $>4500$-fold difference in the corresponding values for GCV. Thus, CdG was not as selective as GCV for HSV-TK-expressing SW620 cells; however, selectivity was similar between $\mathrm{CdG}$ and GCV in the U251 cell lines.

\section{DISCUSSION}

For enzyme-prodrug gene therapy for cancer to be effective clinically, the prodrug must be able to induce the killing of not only the enzyme-expressing cells, but also the neighboring by- 

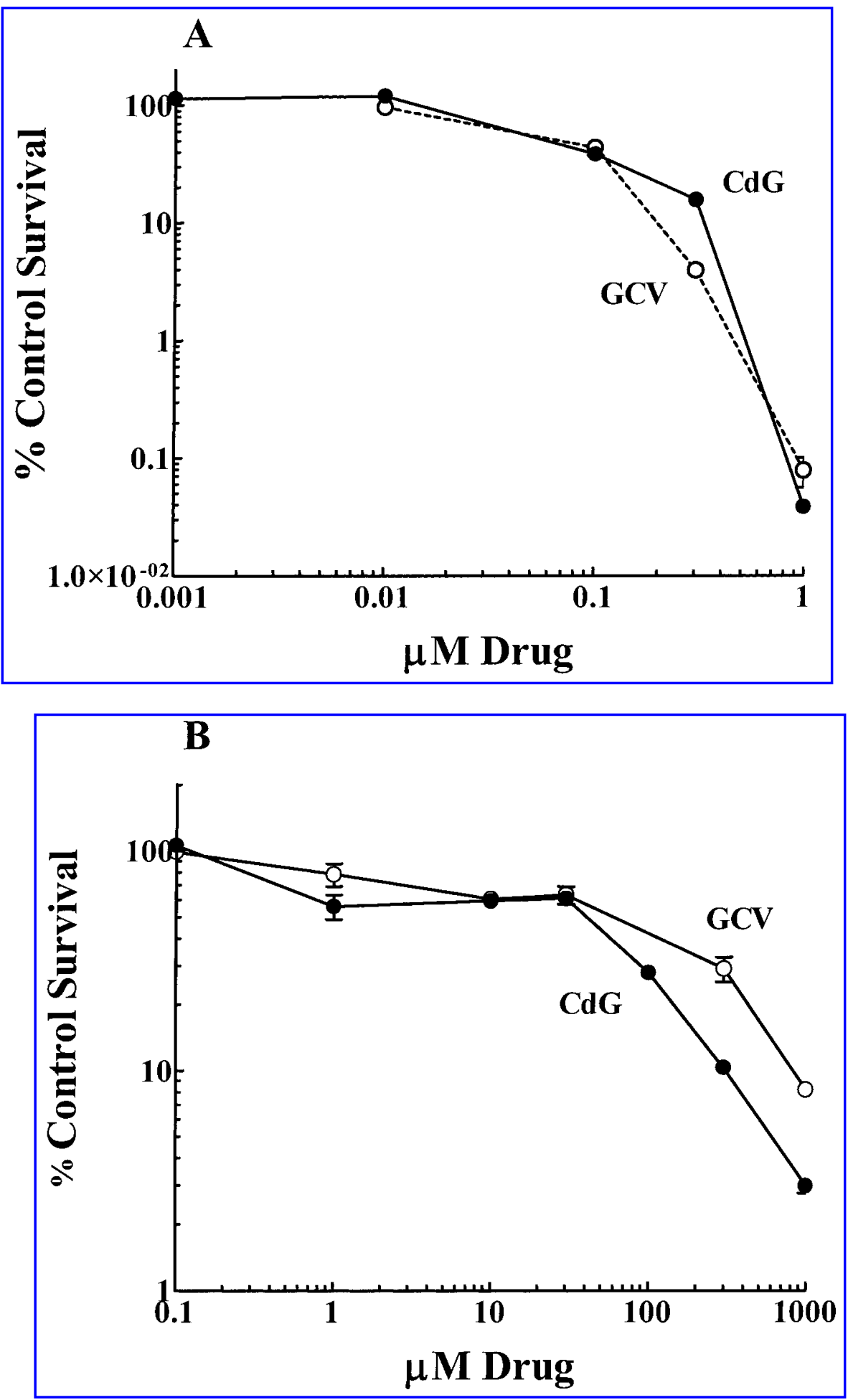

FIG. 1. Comparison of the cytotoxicity of CdG and GCV in U251 cells. U251 cells that express either HSV-TK (U251tk, panel A) or $\beta$-Gal (U251lacZ, B) were incubated with the indicated concentrations of CdG or GCV for 24 hr. Survival was determined at the conclusion of the drug incubation period using a colony formation assay. Each experiment was performed at least three times, and a representative experiment is shown. Values represent average \pm SE of triplicate determinations.

stander (non-transgene-expressing) cells because gene transfer in vivo is estimated to result in gene expression in fewer than $10 \%$ of cells within a tumor (Roth and Cristiano, 1997). Previously, we and others have demonstrated that substrates for
HSV-TK differed significantly in their potency of cytotoxicity to HSV-TK-expressing cells, and that GCV exhibits strong bystander killing ability (Balzarini et al., 1993; Rubsam et al., 1998). Here we report on another antiherpesvirus drug, D-CdG, 


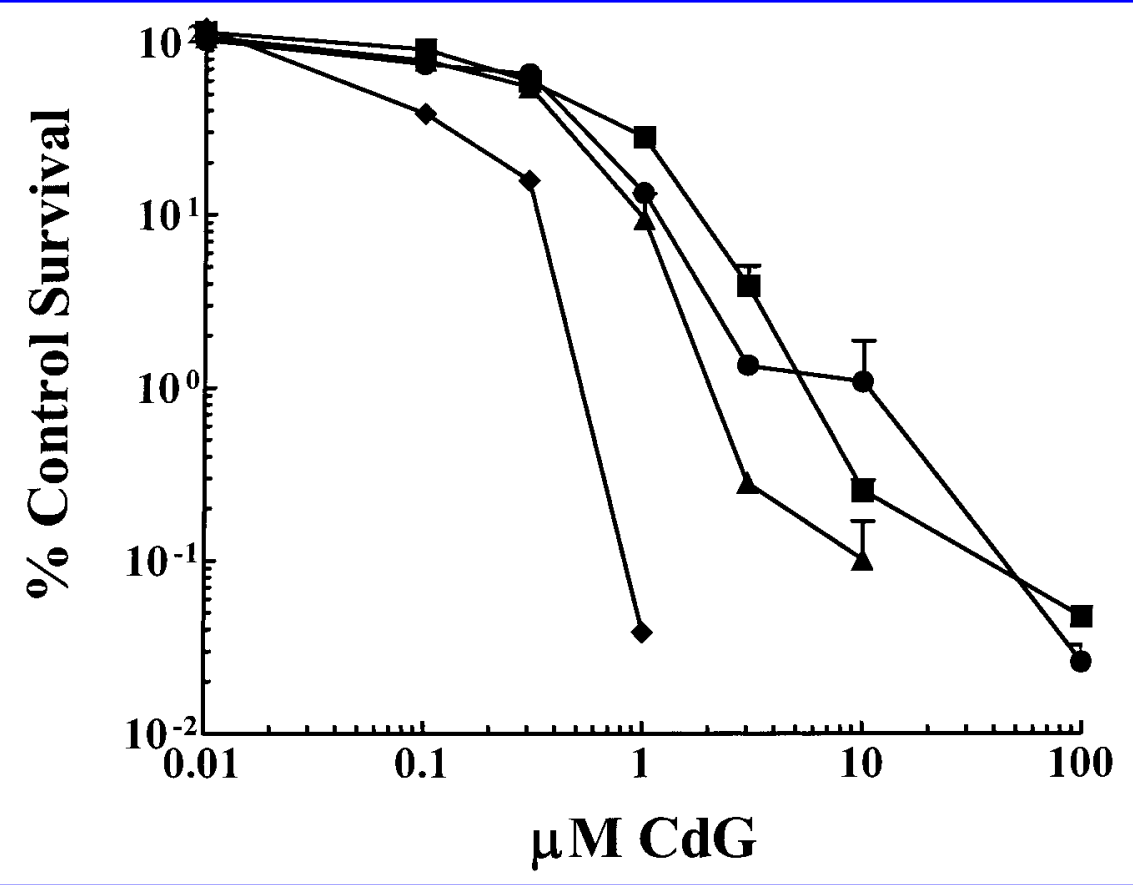

FIG. 2. Effect of length of incubation on cytotoxicity of CdG. U251tk cells were incubated with CdG for 4 ( $\square$ ), $8(\boldsymbol{O}), 12(\boldsymbol{\Delta})$ or $24(\bullet)$ hr. Cell survival was determined by a colony formation assay. Values represent the average \pm SE of triplicate determinations.

with similar potency to the highly cytotoxic GCV in HSV-TKexpressing cells, the ability to induce multi-log cell killing, and excellent bystander cytotoxicity. Although non-HSV-TK-expressing SW620 cells appeared more sensitive to CdG than to
GCV, the strong cytotoxicity of CdG in HSV-TK-expressing and bystander cells in two different cell lines suggests that this drug may have efficacy in vivo.

In the U251 cells, cytotoxicity with $\mathrm{CdG}$ was similar to that

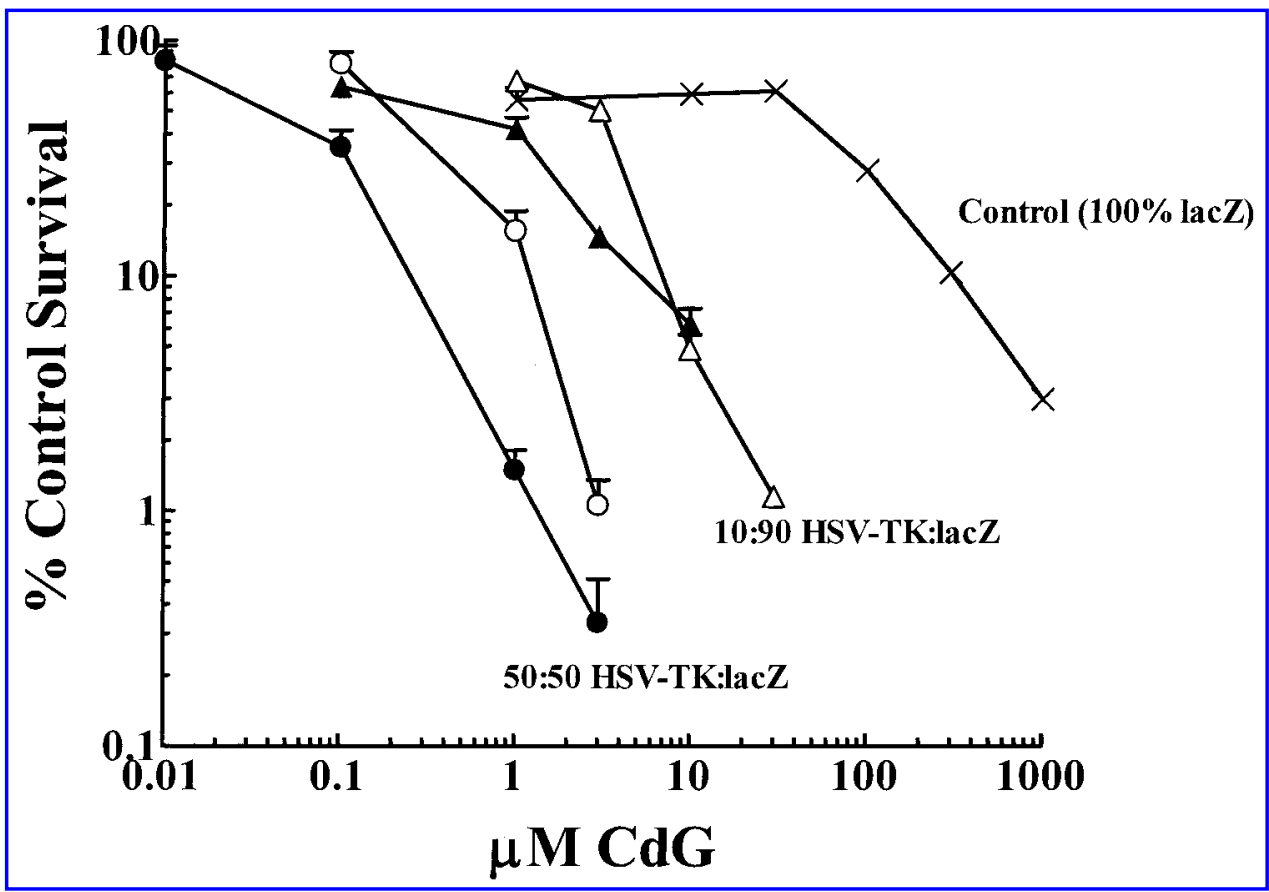

FIG. 3. Cytotoxicity of CdG to HSV-TK-expressing or bystander cells. U251tk cells (filled symbols) and U251lacZ (bystander) cells (open symbols) were co-cultured at ratios of 50:50 (circles) or 10:90 (triangles) with CdG at the indicated concentrations. Control cells (100\% U251lacZ culture) $(X)$ is shown for comparison. This is a representative experiment performed at least three times. Each value represents the average \pm SE of triplicate determinations. 
Table 1. Cell Cycle Distribution of U251tk Cells After CdG Incubation

\begin{tabular}{|c|c|c|c|c|c|c|c|}
\hline \multirow[b]{2}{*}{ Treatment } & \multirow{2}{*}{$\begin{array}{c}\text { Time after drug } \\
\text { washout (hr) }\end{array}$} & \multirow[b]{2}{*}{$G_{1}$} & \multirow[b]{2}{*}{$S$} & \multicolumn{3}{|c|}{ Percentage of cells in: } & \multirow{2}{*}{$\begin{array}{c}\text { Cell } \\
\text { number }\end{array}$} \\
\hline & & & & $G_{2} / M$ & $S_{N I}^{\mathrm{a}}$ & Apoptosis & \\
\hline Control cells & 0 & 58.2 & 26.6 & 9.2 & 3.3 & 2.8 & $1.45 \times 10^{6}$ \\
\hline \multirow[t]{4}{*}{$1 \mu M \mathrm{CdG}$} & 0 & 15.0 & 46.5 & 16.4 & 5.7 & 5.7 & $0.94 \times 10^{6}$ \\
\hline & 24 & 25.7 & 40.4 & 20.1 & 7.8 & 6.0 & $1.19 \times 10^{6}$ \\
\hline & 48 & 29.8 & 20.0 & 20.8 & 13.4 & 16.0 & $1.02 \times 10^{6}$ \\
\hline & 72 & 29.5 & 26.0 & 22.2 & 9.8 & 12.7 & $0.70 \times 10^{6}$ \\
\hline
\end{tabular}

U251tk cells were incubated with $1 \mu M$ CdG for $24 \mathrm{hr}$. Drug-containing medium was replaced with fresh medium (drug washout) and cells were analyzed periodically for cell cycle distribution using dual-parameter (bromodeoxyuridine and propidium iodide) flow cytometry as described in Materials and Methods. Results are from a single representative experiment repeated twice.

${ }^{a} S_{\mathrm{NI}}$, Cells with S-phase DNA content by propidium iodide staining with no significant incorporation of bromodeoxyuridine.

observed with GCV in the HSV-TK-expressing as well as nonHSV-TK-expressing (lacZ) bystander cells, cultured alone or together. However, cell cycle progression differed between these two drugs. Whereas cells incubated with $1 \mu M \mathrm{GCV}$ were able to complete one cell division 24-48 hr after drug washout (Rubsam et al., 1998), following treatment with $1 \mu M \mathrm{CdG}$ the majority of cells did not divide but instead showed an accumulation in S-phase and $\mathrm{G}_{2} / \mathrm{M}$ with a decrease in cell number. Although we did not observe a large increase in $\mathrm{G}_{2} / \mathrm{M}$ with GCV in our cell lines, a report on B16 murine melanoma cells stably expressing HSV-TK indicated that a high percentage of cells accumulated in $\mathrm{G}_{2} / \mathrm{M}$ after a 48-72-hr incubation with a cytotoxic concentration of GCV (Halloran and Fenton, 1998; Wei et al., 1998). We observed only a doubling of the percentage of cells in $\mathrm{G}_{2} / \mathrm{M}$ after treatment with $1 \mu M \mathrm{CdG}$. In addition, the murine melanoma cells did not undergo an apoptotic cell death, whereas in our cell lines both GCV and CdG induced apoptosis, although the onset occurred at approximately $48 \mathrm{hr}$ following drug washout. Thus, multi-log cell killing may occur by different mechanisms depending upon the drug and cell line.

CdG exhibited similar selectivity as GCV for U251tk cells, but was less selective in the SW620 cell lines. It is difficult to translate these in vitro results to in vivo selectivity. For example, it is not known whether $\mathrm{CdG}$ will be as toxic as GCV to bone marrow cells, and drug metabolism and disposition in vivo can affect the therapeutic index. Further studies are needed to determine whether selectivity in vivo differs for these two drugs.

It is not clear why CdG exhibited higher toxicity than GCV in the SW620lacZ cells. It is likely that toxicity in the nonHSV-TK-expressing cell lines was due to minimal phosphorylation by an endogenous enzyme. Previously, it has been demonstrated that deoxycytidine kinase, deoxyguanosine kinase, and $5^{\prime}$-nucleotidase can phosphorylate $\mathrm{L}$ - and $\mathrm{D}-\mathrm{CdG}$ in uninfected mammalian cells (Bennett et al., 1998). Although $\mathrm{L}-\mathrm{CdG}$ was a better substrate than was $\mathrm{D}-\mathrm{CdG}$ for deoxycytidine kinase and deoxyguanosine kinase, it accumulated in intact cells primarily as the monophosphate (Bennett et al., 1993), which may explain the low toxicity of L-CdG to U251 cells. Cytosolic $5^{\prime}$-nucleotidase has also been implicated in the phosphorylation of GCV in non-HSV-TK-expressing MOLT-4 T-lymphoblastic leukemia cells (Agbaria et al., 1994). Differential expression of these enzymes in the two cell lines used in the studies presented here may lead to greater activation of $\mathrm{CdG}$ in

Table 2. Cytotoxicity of CdG and GCV in Human Colon Carcinoma and Glioblastoma Cells

\begin{tabular}{|c|c|c|c|c|}
\hline \multirow[b]{2}{*}{ Cell line } & \multicolumn{2}{|c|}{$[C d G](\mu M)$} & \multicolumn{2}{|c|}{$[G C V](\mu M)$} \\
\hline & $I C_{50}$ & $I C_{90}$ & $I C_{50}$ & $I C_{90}$ \\
\hline SW620tk & 0.9 & 4.5 & 0.07 & 5 \\
\hline SW6201acZ & 90 & 265 & 450 & $>1000$ \\
\hline $\begin{array}{c}50 \% \text { SW620lacZ + } \\
50 \% \text { SW620tk }^{\mathrm{a}}\end{array}$ & 2.4 & 8.7 & 1.5 & 14 \\
\hline $\begin{array}{c}90 \% \text { SW620lacZ + } \\
10 \% \text { SW620tk }^{\mathrm{a}}\end{array}$ & 12 & $>100$ & 55 & 260 \\
\hline U251tk & 0.06 & 0.3 & 0.06 & 0.2 \\
\hline U251lacZ & 40 & 300 & 60 & 800 \\
\hline
\end{tabular}

U251 glioblastoma and SW620 colon carcinoma cells expressing either HSV-TK or $\beta$-Gal were incubated as indicated with $\mathrm{CdG}$ or GCV for $24 \mathrm{hr}$. Cell survival was determined using a colony formation assay.

${ }^{\mathrm{a}} \mathrm{IC}_{50}, \mathrm{IC}_{90}$ values represent survival of bystander cells after co-culture with HSV-TK-expressing cells at the indicated ratios. 
the SW620 cells, resulting in higher cytotoxicity. Previous reports in the literature indicate that $\mathrm{CdG}$ is not highly toxic to normal cells. Human hepatoma cells treated for 10 days with $\mathrm{CdG}$ at $5 \mu \mathrm{g} / \mathrm{ml}$ did not show evidence of toxicity (Price et al., 1989). Similarly, no toxicity was observed in primary duck hepatocyte cultures treated with $10 \mathrm{ng} / \mathrm{ml} \mathrm{CdG}$ for 8 days (Fourel et al., 1994b). Furthermore, in vivo studies in ducks treated with $\mathrm{CdG}$ showed only mild liver abnormalities (hepatocyte vacuolization, mild disruption of lobular architecture) after prolonged administration $(100 \mu \mathrm{g} / \mathrm{kg} \mathrm{CdG}$ administered every other day for 5 weeks) (Fourel et al., 1994a). These results are encouraging, and suggest that $\mathrm{CdG}$ may have low toxicity in humans.

Of all the substrates tested for cytotoxicity in tumor cells expressing HSV-TK, purine analogs have shown higher cytotoxicity compared to the pyrimidine analogs, with good bystander killing (Balzarini et al., 1993; Rubsam et al., 1998; Degreve et $a l ., 1999)$. An evaluation of six guanine analogs that varied in the moiety attached to the base showed a wide variation in cytotoxicity. GCV, its elaidic acid derivative, and a cyclobutyl dervative showed good bystander cell killing, whereas other acyclic analogs such as penciclovir, buciclovir, and acyclovir displayed poor or no bystander cell killing (Degreve et al., 1999). Here we have demonstrated that a carbocyclic guanine analog has high cytotoxicity to HSV-TK-expressing cells with good bystander activity. With so few analogs available that can efficaciously eliminate HSV-TK-expressing as well as nonexpressing bystander cells, further investigation is warranted to compare their antitumor effects in vivo. The drugs that have shown the highest bystander cell killing also show the highest toxicity to non-HSV-TK-expressing cells. Therefore, it will be important to determine whether these analogs have an advantage over the commonly used GCV, such as reduced toxicity to bone marrow cells.

\section{ACKNOWLEDGMENTS}

This study was supported in part by Grant CA76581 from the National Cancer Institute, Grant GM-07767 from the National Institute of General Medical Sciences, the University of Michigan-Comprehensive Cancer Center Grant CA46592 from the National Cancer Institute, University of Michigan Multipurpose Arthritis Center Grant AR20557 from the National Institute of Arthritis and Musculoskeletal and Skin Diseases, and the University of Michigan Core Flow Cytometry Facility.

\section{REFERENCES}

AGBARIA, R., MULLEN, C.A., HARTMAN, N.R., COONEY, D.A., ZHAO, Z., BLAESE, R.M., and JOHNS, D.G. (1994). Effects of IMP dehydrogenase inhibitors on the phosphorylation of ganciclovir in MOLT-4 cells before and after herpes simplex virus thymidine kinase gene transduction. Mol. Pharmacol. 45, 777-782.

AGHI, M., KRAMM, C.M., CHOU, T.-C., BREAKEFIELD, X.O., and CHIOCCA, E.A. (1998). Synergistic anticancer effects of ganciclovir/thymidine kinase and 5-fluorocytosine/cytosine deaminase gene therapies. J. Natl. Cancer Inst. 90, 370-380.

BALZARINI, J., BOHMAN, C., and DECLERCQ, E. (1993). Differential mechanism of cytostatic effect of (E)-5-(2-bromovinyl)-2'-deoxyuridine, 9-(1,3-dihydroxy-2-propoxymethyl)guanine, and other antiherpetic drugs on tumor cells transfected by the thymidine kinase gene of herpes simplex virus type 1 or type 2. J. Biol. Chem. 269, 6332-6337.

BENNETT, L.L., ALlAN, P.W., ARNETT, G., SHEALY, Y.F., SHEWACH, D.S., MASON, W.S., FOUREL, I., and PARKER, W.B. (1998). Metabolism in human cells of the D and L enantiomers of the carbocyclic analog of 2'-deoxyguanosine: Substrate activity with deoxycytidine kinase, mitochondrial deoxyguanosine kinase, and 5'-nucleotidase. Antimicrob. Agents Chemother. 42, 1045-1051.

BENNETT, L.L., PARKER, W.B., ALLAN, P.W., ROSE, L.M., SHEALY, Y.F., SECRIST, J.A., III, MONTGOMERY, J.A., ARNETT, G., KIRKMAN, R.L., and SHANNON, W.M. (1993). Phosphorylation of the enantiomers of the carbocyclic analog of $2^{\prime}$-deoxyguanosine in cells infected with herpes simplex virus type 1 and in uninfected cells. Lack of enantiomeric selectivity with the viral thymidine kinase. Mol. Pharmacol. 44, 1258-1266.

BENNETT, L.L., SHEALY, Y.F., ALLAN, P.W., ROSE, L.M., SHANNON, W.M., and ARNETT, G. (1990). Phosphorylation of the carbocyclic analog of 2'-deoxyguanosine in cells infected with herpes viruses. Biochem. Pharmacol. 40, 1515-1522.

BI, W.L., PARYSEK, L.M., WARNICK, R., and STAMBROOK, P.J. (1993). In vitro evidence that metabolic cooperation is responsible for the bystander effect observed with HSVtk retroviral gene therapy. Hum. Gene Ther. 4, 725-731.

BIRON, K.K., STANAT, S.C., SORRELL, J.B., FYFE, J.A., KELLER, P.M., LAMBE, C.U., and NELSON, D.J. (1985). Metabolic activation of the nucleoside analog 9-\{[2-hydroxy-1-(hydroxymethyl)ethoxy]methyl \}guanine in human diploid fibroblasts infected with human cytomegalovirus. Proc. Natl. Acad. Sci. USA 82, 2473-2477.

BLACK, M.E., NEWCOMB, T.G., WILSON, H.-M.P., and LOEB, L.A. (1996). Creation of drug-specific herpes simplex virus type 1 thymidine kinase mutants for gene therapy. Proc. Natl. Acad. Sci. USA 93, 3525-3529.

BOEHME, R.E. (1984). Phosphorylation of the antiviral precursor 9(1,3-dihydroxy-2-propoxymethyl)guanine monophosphate by guanylate kinase isozymes. J. Biol. Chem. 259, 12346-12349.

BOUCHER, P.D., RUCH, R.J., and SHEWACH, D.S. (1998). Differential ganciclovir-mediated cytotoxicity and bystander killing in human colon carcinoma cell lines expressing herpes simplex virus thymidine kinase. Hum. Gene Ther. 9, 801-814.

BOUCHER, P.D., OSTRUSZKA, L.J., and SHEWACH, D.S. (2000). Synergistic enhancement of herpes simplex virus thymidine kinase/ganciclovir-mediated cytotoxicity by hydroxyurea. Cancer Res. 60, 1631-1636.

CARYSTINOS, G.D., KATABI, M.M., LAIRD, D.W., GALIPEAU, J., CHAN, H., ALAOUI-JAMALI, M.A., and BATIST, G. (1999). Cyclic-AMP induction of gap junctional intercellular communication increases bystander effect in suicide gene therapy. Clin. Cancer Res. 5, 61-68.

CASTLEDEN, S.A., CHONG, H., GARCIA-RIBAS, I., MELCHER, A.A., HUTCHINSON, G., ROBERTS, B., HART, I.R., and VILE, R.G. (1997). A family of bicistronic vectors to enhance both local and systemic antitumor effects of HSVtk or cytokine expression in a murine melanoma model. Hum. Gene Ther. 8, 2087-2102.

CHENG, Y., GRILL, S.P., DUTSCHMAN, G.E., NAKAYAMA, K., and BASTOW, K.F. (1983). Metabolism of 9-(1,3-dihydroxy-2propoxymethyl)guanine, a new anti-herpes virus compound, in herpes simplex virus-infected cells. J. Biol. Chem. 20, 12460-12464.

CULVER, K.W., RAM, Z., WALBRIDGE, S., ISHII, H., OLDFIELD, E.H., and BLAESE, R.M. (1992). In vivo gene transfer with retroviral vector producer cells for treatment of experimental brain tumors. Science 256, 1550-1552.

DEGREVE, B., DE CLERCQ, E., and BALZARINI, J. (1999). Bystander effect of purine nucleoside analogues in HSV-1tk suicide gene therapy is superior to that of pyrimidine nucleoside analogs. Gene Ther. 6, 162-170. 
FIELD, A.K., DAVIES, M.E., DEWITT, C., PERRY, H.C., LIOU, R., GERMERSHAUSEN, J., KARKAS, J.D., ASHTON, W.T., JOHNSTON, D.B.R., and TOLMAN, R.L. (1983). 9-\{[2-Hydroxy-1-(hydroxymethyl)ethoxy]methyl \}guanine: A selective inhibitor of herpes group virus replication. Proc. Natl. Acad. Sci. USA 80, 4139-4143.

FOUREL, I., CULLEN, J.M., SAPUTELLI, J., ALDRICH, C.E., SCHAFFER, P., AVERETT, D.R., PUGH, J., and MASON, W.S. (1994a). Evidence that hepatocyte turnover is required for rapid clearance of duck hepatitis B virus during antiviral therapy of chronically infected ducks. J. Virol. 68, 8321-8330.

FOUREL, I., SAPUTELLI, J., SCHAFFER, P., and MASON, W.S. (1994b). The carbocyclic analog of 2'-deoxyguanosine induces a prolonged inhibition of duck hepatitis B virus DNA synthesis in primary hepatocyte cultures and in the liver. J. Virol. 68, 1059-1065.

FREEMAN, S.M., WHARTENBY, K.A., FREEMAN, J.L., ABBOUD, C.N., and MARROGI, A.J. (1996). In situ use of suicide genes for cancer therapy. Semin. Oncol. 23, 31-45.

FREYTAG, S.O., ROGULSKI, K.R., PAIELLI, D.L., GILBERT, J.D., and KIM, J.H. (1998). A novel three-pronged approach to kill cancer cells selectively: Concomitant viral, double suicide gene, and radiotherapy. Hum. Gene Ther. 9, 1323-1333.

HALLORAN, P.J., and FENTON, R.G. (1998). Irreversible G2-M arrest and cytoskeletal reorganization induced by cytotoxic nucleoside analogues. Cancer Res. 58, 3855-3865.

ILSLEY, D.D., LEE, S.-H., PLUNKETT, W., MILLER, W., and KUCHTA, R.D. (1995). Inhibition of eucaryotic DNA polymerases and DNA primase by acyclic guanosine analogs: Ganciclovir triphosphate is a potent and specific DNA polymerase $\delta$ inhibitor. Biochemistry 34, 2504-2510.

ISHII-MORITA, H., AGBARIA, R., MULLEN, C.A., HIRANO, H., KOEPLIN, D.A., RAM, Z., OLDFIELD, E.H., JOHNS, D.G., and BLAESE, R.M. (1997). Mechanism of 'bystander effect' killing in the herpes simplex thymidine kinase gene therapy model of cancer treatment. Gene Ther. 4, 244-251.

KELLER, P.M., FYFE, J.A., BEAUCHAMP, L., and SPECTOR, T. (1981). Enzymatic phosphorylation of acyclic nucleoside analogs and correlations with antiherpetic activities. Biochem. Pharmacol. 30, 3071-3077.

KOKORIS, M.S., SABO, P., ADMAN, E.T., and BLACK, M.E. (1999). Enhancement of tumor ablation by a selected HSV-1 thymidine kinase mutant. Gene Ther. 6, 1415-1426.

LINK, C.J., LEVY, J.P., MCCANN, L.Z., and MOORMAN, D.W. (1997). Gene therapy for colon cancer with the herpes simplex thymidine kinase gene. J. Surg. Oncol. 64, 289-294.

MOOLTEN, F.L. (1986). Tumor chemosensitivity conferred by inserted herpes thymidine kinase genes: paradigm for a prospective cancer control strategy. Cancer Res. 46, 5276-5281.

MOOLTEN, F.L. (1994). Drug sensitivity ("suicide") genes for selective cancer chemotherapy. Cancer Gene Ther. 1, 279-287.

MURPHY, P.J., PARKER, W.B., SECRIST, J.A., III, and SHEWACH, D.S. (1999). Comparison of cytotoxicity with ganciclovir and carbocyclic deoxyguanosine in HSV-TK-expressing human glioblastoma U251 cells. Proc. Amer. Assoc. Cancer Res. 40: 597

OSTRUSZKA, L.J., and SHEWACH, D.S. (2000). The role of cell cycle progression in radiosensitization by $2^{\prime}, 2^{\prime}$-difluoro- $2^{\prime}$-deoxycytidine. Cancer Res. 60, 6080-6088.

PARK, J.Y., ELSHAMI, A.A., AMIN, K.M., RIZK, N., KAISER, L.R., and ALBELDA, S.M. (1997). Retinoids augment the bystander effect in vitro and in vivo in herpes simplex virus thymidine kinase/ganciclovir-mediated gene therapy. Gene Ther. 4, 909-917.

PARKER, W.B., SHADDIX, S.C., ALLAN, P.W., ARNETT, G., ROSE, L.M., SHANNON, W.M., SHEALY, Y.F., MONTGOMERY, J.A., SECRIST, J.A., III, and BENNETT, L.L., JR. (1992). Incorporation of the carbocyclic analog of 2'-deoxyguanosine into the DNA of herpes simplex virus and of HEp-2 cells infected with herpes simplex virus. Mol. Pharmacol. 41, 245-251.
POPE, I.M., POSTON, G.J., and KINSELLA, A.R. (1997). The role of the bystander effect in suicide gene therapy. Eur. J. Cancer 33, 1005-1016.

PRICE, P.M., BANJEE, R., and ACS, G. (1989). Inhibition of the replication of hepatitis B virus by the carbocyclic analogue of $2^{\prime}$-deoxyguanosine. Proc. Natl. Acad. Sci. USA 86, 8541-8544.

QIAO, J., BLACK, M., and CARUSO, M. (2000). Enhanced ganciclovir killing and bystander effect of human tumor cells transduced with a retroviral vector carrying a herpes simplex virus thymidine kinase gene mutant. Hum. Gene Ther. 11, 1569-1576.

RAINOV, N.G. (2000). A phase III clinical evaluation of herpes simplex virus type 1 thymidine kinase and ganciclovir gene therapy as an adjuvant to surgical resection and radiation in adults with previously untreated glioblastoma multiforme. Hum. Gene Ther. 11, 2389-2401.

RAM, Z., CULVER, K.W., WALBRIDGE, S., BLAESE, R.M., and OLDFIELD, E.H. (1993). In situ retroviral-mediated gene transfer for the treatment of brain tumors in rats. Cancer Res. 53, 83-88.

REARDON, J.E. (1989). Herpes simplex virus type 1 and human DNA polymerase interactions with $2^{\prime}$-deoxyguanosine $5^{\prime}$-triphosphate analogues. J. Biol. Chem. 264, 19039-19044.

REID, R., MAR, E.-C., HUANG, E.-S., and TOPAL, M.D. (1988). Insertion and extension of acyclic, dideoxy, and ara nucleotides by herpesviridae, human $\alpha$ and human $\beta$ polymerases. J. Biol. Chem. 263, 3898-3904.

ROBE, P.A., PRINCEN, F., MARTIN, D., MALGRANGE, B., STEVENAERT, A., MOONEN, G., GIELEN, J., MERVILLE, M.-P., and BOURS, V. (2000). Pharmacological modulation of the bystander effect in the herpes simplex virus thymidine kinase/ganciclovir gene therapy system. Effects of dibutyryl adenosine $3^{\prime}, 5^{\prime}$ cyclic monophosphate, $\alpha$-glycerrhetinic acid, and cytosine arabinoside. Biochem. Pharmacol. 60, 241-249.

ROTH, J.A., and CRISTIANO, R.J. (1997). Gene therapy for cancer: What have we done and where are we going? J. Natl. Cancer Inst. 89, 21-39.

RUBSAM, L.Z., DAVIDSON, B.L., and SHEWACH, D.S. (1998). Superior cytotoxicity with ganciclovir compared to acyclovir and araT in HSV-TK-expressing cells: A novel paradigm for cell killing. Cancer Res. 58, 3873-3882.

RUBSAM, L.Z., BOUCHER, P.D., MURPHY, P.J., KUKURUGA, M., and SHEWACH, D.S. (1999). Cytotoxicity and accumulation of ganciclovir triphosphate in bystander cells cocultured with herpes simplex virus type 1 thymidine kinase-expressing human glioblastoma cells. Cancer Res. 59, 669-675.

SHAND, N., WEBER, F., MARIANI, L., BERNSTEIN, M., GIANELLA-BORRADORI, A., LONG, Z., SORENSEN, A.G., and BARBIER, N. (1999). A phase 1-2 clinical trial of gene therapy for recurrent glioblastoma multiforme by tumor transduction with the herpes simplex thymidine kinase gene followed by ganciclovir. $\underline{\text { Hum. }}$ Gene Ther. 10, 2325-2335.

SHEWACH, D.S., ZERBE, L.K., HUGHES, T.L., ROESSLER, B.J., BREAKEFIELD, X.O., and DAVIDSON, B.L. (1994). Enhanced cytotoxicity of antiviral drugs mediated by adenovirus directed transfer of the herpes simplex virus thymidine kinase gene in rat glioma cells. Cancer Gene Ther. 1, 107-112.

ST.CLAIR, M.H., LAMBE, C.U., and FURMAN, P.A. (1987). Inhibition by ganciclovir of cell growth and DNA synthesis of cells biochemically transformed with herpesvirus genetic information. Antimicrob. Agents Chemother. 31, 844-849.

TOURAINE, R.L., VAHANIAN, N., RAMSEY, W.J., and BLAESE, R.M. (1998). Enhancement of the herpes simplex virus thymidine kinase/ganciclovir bystander effect and its antitumor efficacy in vivo by pharmacologic manipulation of gap junctions. Hum. Gene Ther. 9, 2385-2391.

TRASK, R.W., TRASK, R.P., AGUILAR-CORDOVA, E., SHINE, H.D., WYDE, P.R., GOODMAN, J.C., HAMILTON, W.J., ROJAS- 
MARTINEZ, A., CHEN, S.-H., WOO, S.L.C., and GROSSMAN, R.G. (2000). Phase I study of adenoviral delivery of the HSV-tk gene and ganciclovir administration in patients with recurrent malignant brain tumors. Mol. Ther. 1, 195-203.

WEI, S.-J., CHAO, Y., HUNG, Y.-M., LIN, W., YANG, D.-M., SHIH, Y.-L., CH'ANG, L.-Y., WHANG-PENG, J., and YANG, W.K. (1998). S- and G2-phase cell cycle arrests and apoptosis induced by ganciclovir in murine melanoma cells transduced with herpes simplex virus thymidine kinase. Exp. Cell Res. 241, 66-75.

WILDNER, O., BLAESE, R.M., and CANDOTTI, F. (1999). Enzyme prodrug gene therapy: Synergistic use of the herpes simplex viruscellular thymidine kinase/ganciclovir system and thymidylate synthase inhibitors for the treatment of colon cancer. Cancer Res. 59, 5233-5238.
Address reprint requests to:

Donna S. Shewach, Ph.D. 4713 Upjohn Center for Clinical Pharmacology

University of Michigan Medical Center

1310 E. Catherine

Ann Arbor, MI 48109-0504

E-mail: dshewach@umich.edu

Received for publication August 15, 2002; accepted after revision January 28, 2002.

Published online: February 18, 2002. 